\title{
Efficiency in nitrogen management using conventional and transgenic technology in the cultivation of maize
}

\author{
Ivan Ricardo Carvalho, ${ }^{1,}{ }^{\circ}$, Márcio Peter ${ }^{2}{ }^{\circ}$, Gustavo Henrique Demari ${ }^{2}$, Francine \\ Lautenchleger ${ }^{2}\left(\mathbb{D}\right.$, Filipe Selau Carlos ${ }^{2} \odot$, Tiago Pedó ${ }^{2} \odot$, Victor Delino Barasuol Scarton ${ }^{1} \oplus$, Aline \\ Danielle Novello da Silva ${ }^{1}$, Danieli Jacoboski Hutra ${ }^{1} \mathbb{D}$ and Murilo Vieira Loro ${ }^{1} \mathbb{C}$

\begin{abstract}
${ }^{1}$ Universidade Regional do Noroeste do Estado do Rio Grande do Sul. R. do Comércio, 3000, CEP 98700-000 - Uniljuí, RS, Brazil. ${ }^{2}$ Federal University of Pelotas, Department of Plant Science - Eliseu Maciel Avenue, no number - 96160000 - Capão do Leão, RS, Brazil. *Corresponding author, E-mail: ivan.carvalho@unijui.edu.br
\end{abstract}

\begin{abstract}
The objective to evaluate the maize yield components as a function of the top-dressing nitrogen partitioning in maize plants with conventional and transgenic technology. The experiment was carried out in the agricultural crops of 2012/2013 and 2013/2014, in the municipality of Tenente Portela-RS, Brazil. The experiment was set up in a randomized block design in a factorial scheme with two genetic technologies $\mathrm{x}$ 11 nitrogen fertilization treatments, arranged in three replications. The treatments were composed of topdressing applications in the phenological stages V2 - two fully expanded leaves, (V2), V4 - four fully expanded leaves, (V4), V6 - six fully expanded leaves (V6) and V8 - with eight fully expanded leaves (V8) and split applications in $\mathrm{V} 2+\mathrm{V} 4 ; \mathrm{V} 2+\mathrm{V} 6 ; \mathrm{V} 2+\mathrm{V} 8 ; \mathrm{V} 4+\mathrm{V} 6 ; \mathrm{V} 4+\mathrm{V} 8 ; \mathrm{V} 6+\mathrm{V} 8$; and $\mathrm{V} 2+\mathrm{V} 4+\mathrm{V} 6+\mathrm{V} 8$. There was interaction between genetic technologies and levels of nitrogen fertilization in the maize crop. The highest grain yield was obtained with conventional technology because it presented plants with greater prolificacy, ear diameter and number of grains per row. Grain yield was superior with nitrogen fertilization in $\mathrm{V} 4$ and in nitrogen splitting in the V4 + V6, V4 + V8 and V2 + V4 + V6 + V8 stages.
\end{abstract}

Keywords: Genetically modified hybrids, trends genetics, causal diagram, agronomic practices, plant metabolism, nitrogen effect.

\section{INTRODUCTION}

Maize (Zea mays L.) is the most produced cereal in Brazil in cultivated area and volume of production. National production of the grain in the $2017 / 18$ crop showed an average yield of more than $5.5 \mathrm{t} \mathrm{ha}^{-1}$ (Companhia Nacional de Abastecimento [CONAB], 2018), mainly due to the use of a high technological level regarding the use of hybrids and intensive crop management. However, national productivity is still below the potential productivity, that can reach 16 to $18 \mathrm{t} \mathrm{ha}^{-1}$ (Sangoi et al., 2011; Sauer, et al., 2015; Santos, Bizzarri, Barbosa, \& Zucareli, 2017; Escanferla, Wysmierski, Meirelles, \& Paccola-Meirelles, 2018; Rosa et al., 2019).

The genetic factor is fundamental in the construction of high yield crops. In general, hybrids of maize have a productive potential superior to conventional cultivars, however, to obtain high yields, the use of hybrids requires the adoption of more careful agronomic practices, especially in relation to nutritional management (Crawford, Rendig, \& Broadbent, 1982).

Nitrogen $(\mathrm{N})$ is one of the more limiting macronutrients required by the plants and made available by the soil, to the development of summer grasses in tropical and subtropical soils. (Beatty et al., 2010, Mir et al., 2010). Nitrogen (N) participates in plant metabolism, helps in the formation of leaf area, helps to capture light energy and carbon accumulation between vegetative and reproductive tissues. In this way, studies have shown that the increase in the supply of $N$ is associated to the increase of the thousand grain mass (Sangoi et al., 2011; Andrade, Petter, Nóbrega, Pacheco, \& Zuffo, 2014), reflecting the yield. In contrast, the use of nitrogen fertilization may lead to an increase in the accumulation of vegetative dry matter (Andrade et al., 2014) and reduction of photoassimilate allocation to grains (Souza et al., 2011).

During the development of the plants, the number of leaves and ears are determined in the initial periods of the crop in V3, while the number of grains and rows are defined until the V8 stage (Magalhães, Durães, 
Carneiro, \& Paiva, 2002). These can have repercussions on success since they are closely associated with crop yield. The efficiency of this nutrient is related to the application time for the crop development (Mar, Marchetti, Souza, Gonçalves, \& Novelino, 2003; Deng et al., 2019), environmental conditions, soil, cultivars and interaction with other nutrients (Sims, Schepers, Olson, \& Power, 1998). The application of nitrogen for top-dressing has maximized the utilization of this nutrient by the crop (Arf, Rodrigues, Nascente, \& Lacerda, 2015). However, it is important to consider the vegetative stage of maize in which top-dressing will be performed (Büll, 1993), and there are still gaps in the knowledge regarding the most appropriate moment and proportion for application of nitrogen fertilizer in maize crop, comparing conventional and transgenic cultivars.

Therefore, the evaluation of the productive performance of the plants is an important tool for a better understanding of the effect of nitrogen for top-dressing in maize plants with different technological levels. In view of the above, this work had as objective to evaluate the maize yield components as a function of the top-dressing nitrogen partitioning in maize plants with conventional and transgenic technology.

\section{MATERIAL AND METHODS}

The experiment was carried out in the agricultural crops of 2012/2013 and 2013/2014, in the municipality of Tenente Portela-RS with coordinates of Latitude $27^{\circ} 23^{\prime} 31.04$ "S and Longitude $53^{\circ} 46^{\prime} 50.71^{\prime \prime}$ W with an altitude of $\mathbf{4 2 0}$ meters. The climate according to the classification of Köppen is subtropical humid of the type Cfa. The soil is classified in typical Aluminoferric Red Latosol (Oxisol).

For the installation of the experiment, a soil analysis was carried out at depth of $0-10 \mathrm{~cm}$ where the presence of $64 \%$ of clay was verified; $\mathrm{pH}$ in water of 6.0; SMP index of 6.3; Phosphorus (P) of $4.3 \mathrm{mg} \mathrm{I}^{-1}$; Potassium (K) of $159.5 \mathrm{mg} \mathrm{l}^{-1}$; Sulfur (S) $18.9 \mathrm{mg} \mathrm{l}^{-1}$; Organic matter (OM) of $2.9 \%$; Toxic aluminum (AL) of 0,0 $\mathrm{cmolc}^{-1}$; Calcium (Ca) of $6.1 \mathrm{cmol} \mathrm{I}^{-1}$; Magnesium (Mg) of $2.8 \mathrm{cmolc}^{-1}$ and cation exchange capacity (CEC) of $12.0 \mathrm{cmolc} \mathrm{l}^{-1}$.

The experiment was set up in a randomized block design in a factorial scheme with two genetic technologies $x 11$ nitrogen fertilization treatments, arranged in three replications. The experimental units were composed of 4 lines with three meters in length. For the evaluations, the two external lines and 0.25 meters at the ends of the plots were unvalued in order to reduce the border effect, using the two central lines, with a useful area of $2.25 \mathrm{~m}^{2}$.

The treatments were composed of top-dressing applications in the phenological stages V2 - two fully expanded leaves, (V2), V4 - four fully expanded leaves, (V4), V6 - six fully expanded leaves (V6) and V8 with eight fully expanded leaves (V8) and split applications in V2+V4; V2+V6; V2+V8; V4+V6; V4+V8; V6+V8; and V2+V4+V6+V8, described in Table 1 (Fancelli \& Dourado-Neto, 1997).

Table 1. Treatments with percentage distribution and phenological stages of nitrogen fertilization application in maize crop.

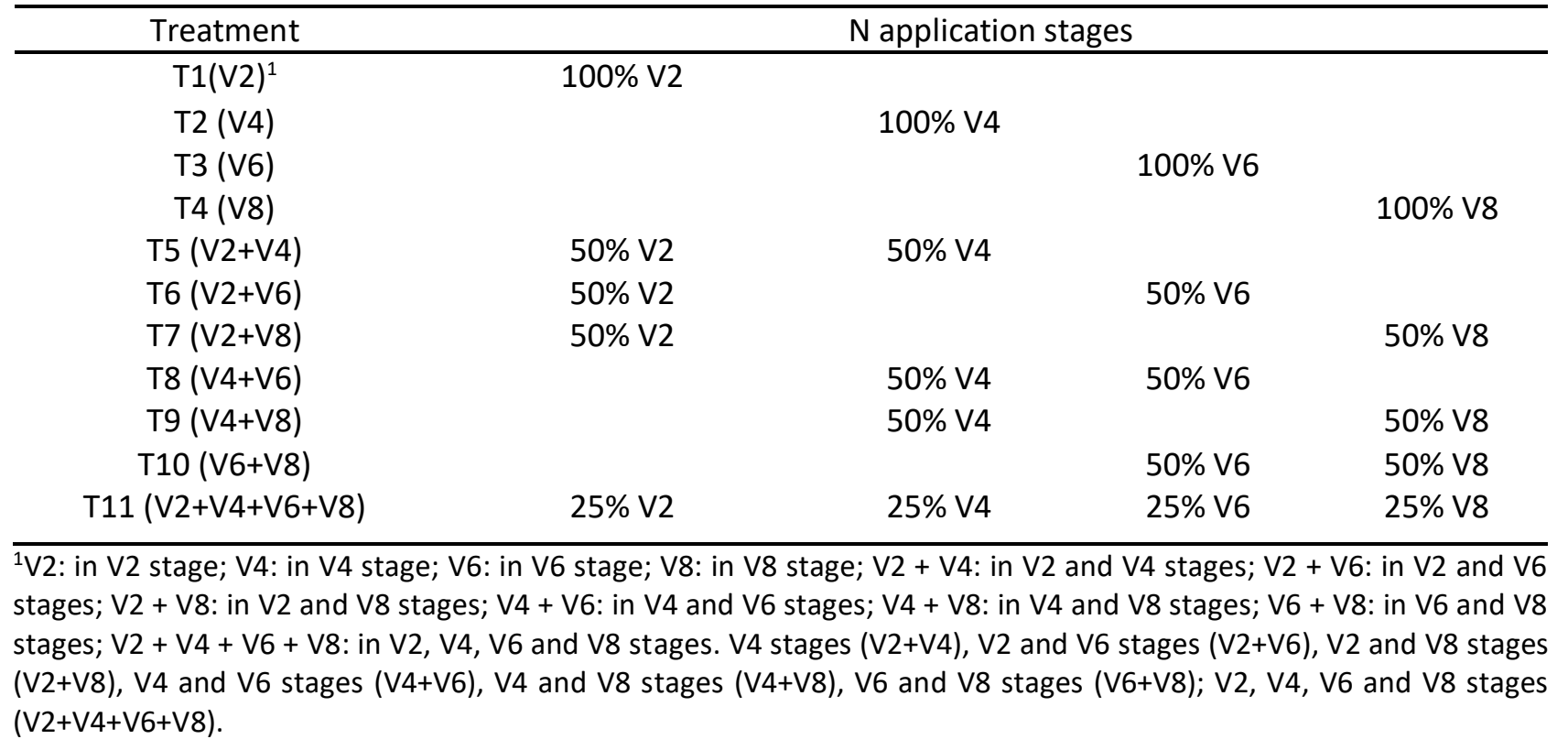


The sowing was performed in a no-tillage system on black oat (Avena strigosa L.) with white radish straw (Raphanus sativus L.) in the second half of September 2012 and in the first half of October 2013, with a final population of 75,000 plants per hectare. Hybrids used in the experiment were DKB 240 VT PRO3 ${ }^{\circledR}$ and DKB 240 conventional. The base fertilization was $450 \mathrm{~kg}$ ha-1 with NPK fertilizer with formulation (10-20-20), the top-dressing fertilizations were $202.5 \mathrm{~kg}$ ha-1 of nitrogen, by broadcasting, according to the treatment (Comissão de Química e Fertilidade do Solo [CQFS-RS/SC], 2016).

In order to carry out the evaluations, three plants representative of the useful area of each plot were evaluated: plant height $(\mathrm{PH}, \mathrm{m})$, ear height $(E H, m)$, prolificacy $(P R)$, ear diameter $(E D, m m)$, ear length (EL, $\mathrm{cm}$ ), number of grains per row (NG, unit), number of rows per ear (NR, unit), grain mass per ear (GM, g), cob diameter (CD, g), cob mass (CM, g), ear mass (EM, g), thousand grain mass ( $T M, g)$, yield $\left.(Y), \mathrm{kg} \mathrm{ha}^{-1}\right)$.

The data were submitted to the diagnosis of normality and homogeneity of the residue variances, after which the results were submitted to analysis of variance by the $F$ test at $5 \%$ level of significance, through SAS statistical program. For the significant results the simple effects between genetic technology and nitrogen managements were deployed. Not significant variables for the interaction, but rather for the main factor, were compared by the Tukey test at $5 \%$ probability.

\section{RESULTS AND DISCUSSION}

The yield of maize grains in all nitrogen managements was not significant in the interaction between genetic technologies (TEC) and nitrogen managements (N). In contrast, the grain mass per ear (GM), cob diameter (CD), cob mass (CM) and ear mass (EM) were shown to be significant (Table 2). However, nitrogen management significantly affected plant height (PH), ear insertion height (EH), prolificacy (PR), number of rows per ear (NR), cob diameter (CD), and the yield ( $\mathrm{YI})$. These differences are related to the absorption of this nutrient throughout the vegetative cycle (MAR et al., 2003), to the appropriate management and time of nitrogen application (Okumura, Mariano, Vicente, \& Zaccheo, 2011).

Regarding the technology, it was verified that only the thousand grain mass (TM) did not present significance at $5 \%$ level. When analyzing the effect of technologies on the maize yield, conventional plants presented higher prolificacy (PR), ear diameter (ED), cob mass (CM), number of grains per row (NG) and yield ( $\mathrm{YI}$ ), comparing to the transgenic ones (Table 2). However, for ear height (EH), ear length (EL) and number of rows per ear (NR) the transgenic plants presented superior performance when compared to conventional ones.

The height of maize plants $(\mathrm{PH})$ between conventional and transgenic genetic technologies did not show significant differences (Table 2). The highest PH was observed in the nitrogen applications in the V2 and V4 stages, and in the split applications in $\mathrm{V} 2+\mathrm{V} 4, \mathrm{~V} 2+\mathrm{V} 8, \mathrm{~V} 4+\mathrm{V} 6, \mathrm{~V} 4+\mathrm{V} 8$ and $\mathrm{V} 2+\mathrm{V} 4+\mathrm{V} 6+\mathrm{V} 8$ and lower with the application in the $\mathrm{V} 6+\mathrm{V} 8$ stage. Although, ear height (EH) showed that maize plants with transgenic technology were higher than conventional ones (Table 3). The highest ear insertion heights (EH) were observed when the nitrogen was applied in the V4 stage and when it was parceled in the V2 + V4 and V4 + V6 stages.

The application of $\mathrm{N}$ assists in the interception of solar radiation in photosynthetically active regions (Mir et al., 2010), probably by increasing the leaf area in maize plants under the effect of greater availability of N. Differential plant and ear insertion heights responses are attributed to the genotype, with little influence by maize management practices (Zucareli, Alves, Oliveira, \& Machado, 2014), which was not observed in this work.

Prolificity (PR) was higher in conventional plants and lower in transgenic plants (Table 3 ). The PR was higher when the $\mathrm{N}$ was parceled in the $\mathrm{V} 2+\mathrm{V} 6, \mathrm{~V} 4+\mathrm{V} 6$ and $\mathrm{V} 4+\mathrm{V} 8$ stages. The PR is important for the determination of the grain yield, since it composes the largest number of ears per $\mathrm{m}^{2}$. The ear diameter (ED) was higher in the conventional TEC in relation to transgenic, while the ear length (EL) was higher in the transgenic TEC (Table 3). Nitrogen management at all stages of development did not significantly affect ED and EL. According to Kappes, Carvalho, Yamashita and Silva, (2009), the ear length may interfere with the number of grains per row, being an important variable for maize productivity, being able to be maximized as a function of the time of $\mathrm{N}$ application (Andrade et al., 2014).

The highest number of rows per ear (NR) was found in transgenic maize plants (Table 3 ). In contrast, the number of grains per row (NG) was higher in conventional plants. The NR under the different $N$ treatments was lower in the V6 application compared to the other stages, whereas the NG did not demonstrate significance among all the nitrogenated managements. Results differ from those obtained by Zucareli et al. (2014) when evaluating maize yield in response to times of nitrogen application, did not observe significant 
differences for number of grain row per ear. The ability to form grains, in terms of row number and number of grains per row are closely linked to the genetic factor, however the availability of nutrients may compromise the response, so that for the present study the exclusive application of $\mathrm{N}$ fertilizer in the $\mathrm{V} 6$ stage reduced the magnitude of both variables.

Cob mass (CM) was higher in conventional plants compared to transgenic plants (Table 3). Although we analyzed the effect of $\mathrm{N}$ management in the $\mathrm{V} 6$ stage, it was the one that presented the lowest $\mathrm{CM}$.

There was no difference between the values of the thousand grain mass (TM) between conventional and transgenic TEC (Table 3). Souza et al. (2011) did not observe significant differences with the use of nitrogen in maize, which was similar for most treatments of the present study. However the use of exclusive nitrogen fertilization in V2 was inferior and significant to the best treatment.

However, in the absence of a significant difference, the increase in the magnitude of thousand grain mass was observed, thus, influenced by the $\mathrm{N}$ splitting for top-dressing (Zucareli et al., 2014), with increased dose (Sangoi et al., 2011; Andrade et al., 2014) and with the high availability of N (Queiroz et al., 2011). The higher availability of $\mathrm{N}$ throughout the development of the plants favors the production of photoassimilates, increasing the accumulation of reserves in the grains.

Grain yield (YI) was higher in conventional maize plants when compared to transgenic maize (Table 3 ). The highest grain yield was observed in the treatment with nitrogen splitting fertilization in V4 + V6, not differing from the other treatments, except for the treatments with nitrogen fertilization in single application in the V2, V8 and V6 stages where the lowest yields were verified. The lower yield observed in the single application of $\mathrm{N}$ in $\mathrm{V} 2$ may be associated to the great nutrient supply to the plant at a stage of low development and low nutritional demand, which may be reducing the availability of the element in the subsequent phenological stages. In relation to the lower single productivity in V6 and V8 it is observed, on the other hand, that the lack of availability and supply of $\mathrm{N}$ for plants prior to these stages must have generated a period of $\mathrm{N}$ deficiency, compromising the full functioning of plant metabolism, penalizing the reduction of grain yield.

The yield of grains has complex environmental and genetic associations, since it is the final product of the process of growth and development of the crop. The use of embedded technology seems to influence grain yield. However, this technology aims to reduce the use of water and agrochemicals to control insect pests, so the choice of genotype and its respective embedded technology should have a broad holistic view of the market. So, that even with the reduction in grain yield the net balance of the producer may be greater, since there is a reduction of costs with the necessary management procedures.

In a consensus, the availability during the development period favors the increment of the grain yield. So, as to avoid losses by leaching and better utilization of the nutrient, since it comprises an essential role for the growth of the plants because they constitute a portion of the proteins, chlorophyll and are associated with morphological and physiological changes, and participate in important metabolic routes (Andrade et al., 2014).

There was interaction between management and technologies for cob diameter (CD), grain mass per ear (GM) and ear mass (EM) (Table 3). For the character of CD it is sought smaller magnitudes since it represents an energy consumption that could be directed to the grains. Thus, smaller magnitudes were observed among the technologies for the transgenic for the treatments with nitrogen fertilization in V4, V6 and V4 + V8. Regarding the nitrogen fertilization management in the conventional technology, the smallest magnitude was observed in the $\mathrm{V} 2+\mathrm{V} 8$ treatment, but for the transgenic technology, the smallest magnitude was observed in the $\mathrm{V} 6$ treatment.

The highest grain mass per ear was observed in conventional maize plants when compared to the transgenic V2, V4, V6, V2 + V6 and V4 + V8 treatments (Table 4). For nitrogen management in the conventional hybrid, the highest GM was observed in the V4 treatment and did not differ statistically from the others, except for the V2 + V4 treatment, where it was lower and statistically different. For the transgenic technology the highest GM was observed in the $\mathrm{V} 2+\mathrm{V} 4+\mathrm{V} 6+\mathrm{V} 8$ treatment, not differing from the $\mathrm{V} 4, \mathrm{~V} 8, \mathrm{~V} 2+\mathrm{V} 4, \mathrm{~V} 2+\mathrm{V} 8, \mathrm{~V} 4+\mathrm{V} 6$ and $\mathrm{V} 6+\mathrm{V} 8$ treatments

The ear mass presented superiority in the conventional technology in relation to the transgenic ones for the treatments V2, V4, V6 and V2 + V6 (Table 4). Regarding the effects of nitrogen fertilization on conventional technology, the treatment that stood out was V4 differing only from V2 + V4, which was lower and statistically different. For the transgenic technology, the highest magnitude was observed in the treatment in $\mathrm{V} 2+\mathrm{V} 4+\mathrm{V} 6+\mathrm{V} 8$ and the lowest in the $\mathrm{V} 2$ treatment differing statistically. 
These responses may be related to increased $\mathrm{N}$ content in maize leaves (Moda et al., 2014), and may be translocated to the reproductive structures conferring greater yield of maize grains. The explanatory model demonstrates the effect of the treatments on each evaluated character and its importance for the grain yield (Table 5).

Table 2: Summary of the analysis of variance with the average tables for plant height (PH, cm), ear height (EH, $\mathrm{cm})$, prolificity (PR, unids), ear diameter (ED, mm), ear length (EL, cm), number of grains per row (NG, unids), number of rows per ear (NR, unids), grain mass per ear (GM, g), cob diameter (CD, mm), cob mass (CM, $\mathrm{g})$, ear mass (EM, g), thousand grains mass (TM, g), yield $\left(\mathrm{YI}, \mathrm{kg} \mathrm{ha}^{-1}\right)$.

\begin{tabular}{|c|c|c|c|c|c|c|c|c|}
\hline \multicolumn{9}{|c|}{ ANOVA } \\
\hline \multirow[t]{2}{*}{ VS } & \multirow[t]{2}{*}{ DF } & \multicolumn{7}{|c|}{ Mean Square } \\
\hline & & PH & EH & PR & ED & EL & NG & NR \\
\hline Technology (TEC) & 1 & $0.12 *$ & $0.629 *$ & $0.153^{*}$ & $27.66^{*}$ & $4.62 *$ & $582.45^{*}$ & 78.76* \\
\hline Management (MA) & 10 & $0.037^{*}$ & $0.045^{*}$ & $0.08^{*}$ & $2.95^{\mathrm{ns}}$ & $0.311^{\mathrm{ns}}$ & $3.32^{\mathrm{ns}}$ & $1.65^{*}$ \\
\hline TEC* MA & 10 & $0.028^{\mathrm{ns}}$ & $0.021^{\mathrm{ns}}$ & $0.028^{\mathrm{ns}}$ & $2.65^{\mathrm{ns}}$ & $1.11^{\mathrm{ns}}$ & $7.72^{\mathrm{ns}}$ & $0.919^{\text {ns }}$ \\
\hline Block & 17 & 3.25 & 0.006 & 0.031 & 3.27 & 2.02 & 7.88 & 1.11 \\
\hline Residue & 338 & 0.016 & 0.012 & 0.02 & 2.31 & 0.701 & 58.08 & 0.73 \\
\hline \multirow[t]{2}{*}{ CV (\%) } & & 6.1 & 8.1 & 13.2 & 3.4 & 5.2 & 7.58 & 6.1 \\
\hline & & GM & CD & CM & EM & TM & YI & \\
\hline Technology (TEC) & 1 & $5351.55^{*}$ & $10.51 *$ & $400.63^{*}$ & $6745.75^{*}$ & $2437.18^{\text {ns }}$ & $19122491^{*}$ & \\
\hline Management (MA) & 10 & $231.76^{\mathrm{ns}}$ & $3.71 *$ & $3.75^{\mathrm{ns}}$ & $520.06^{\text {ns }}$ & $932.79^{\text {ns }}$ & 8760829* & \\
\hline TEC* MA & 10 & $357.01 *$ & $3.19 *$ & $8.35^{*}$ & $748.82 *$ & $774.89^{\text {ns }}$ & $5138662^{\text {ns }}$ & \\
\hline Block & 17 & 2049.13 & 4.23 & 20.37 & 2164.8 & 3200.7 & 230328589 & \\
\hline Residue & 376 & 368.71 & 1.31 & 4.79 & 363.4 & 740.4 & 2864175 & \\
\hline CV (\%) & & 12.3 & 5.07 & 12.8 & 12.2 & 9.9 & 18.3 & \\
\hline
\end{tabular}

${ }^{*}$ and $^{\text {ns }}$ - significant at 5\% probability and not significant, respectively; VS - Variation source; DF - degrees of freedom; CV - coefficient of variation. 
Table 3: Average results for plant height $(\mathrm{PH}, \mathrm{m})$, ear height $(\mathrm{EH}, \mathrm{m})$, prolificity (PR, unidade), ear diameter (ED, $\mathrm{mm}$ ), ear length (EL, $\mathrm{cm}$ ), number of rows per ear (NR, unidade), cob mass (CM, g), number of grains per row (NG, unidade), thousand grains mass (TM, g) and yield (YI, kg) for technologies and management.

\begin{tabular}{|c|c|c|c|c|c|c|c|c|c|c|}
\hline Technology ${ }^{1}$ & $\mathrm{PH}$ & $\mathrm{EH}$ & PR & ED & EL & NR & $\mathrm{CM}$ & NG & TM & $\mathrm{YI}$ \\
\hline Conventional & $2.05 a$ & $1.32 \mathrm{~b}$ & $1.1 \mathrm{a}$ & $44.01 \mathrm{a}$ & $15.98 \mathrm{~b}$ & $13.38 b$ & $18.05 \mathrm{a}$ & $38.24 \mathrm{a}$ & $276.6 \mathrm{a}$ & $9406.0 \mathrm{a}$ \\
\hline Transgenic & $2.08 \mathrm{a}$ & $1.4 \mathrm{a}$ & $1.06 \mathrm{~b}$ & $43.47 b$ & $16.2 \mathrm{a}$ & $14.28 \mathrm{a}$ & $16.01 \mathrm{~b}$ & $35.75 b$ & $271.55 \mathrm{a}$ & $9021.8 \mathrm{~b}$ \\
\hline Management & $\mathrm{PH}$ & $\mathrm{EH}$ & PR & ED & EL & NR & $\mathrm{CM}$ & NG & TM & $\mathrm{YI}$ \\
\hline $\mathrm{V} 2^{2}$ & $2.09 a b$ & $1.36 \mathrm{bcd}$ & $1.04 \mathrm{cbd}$ & $43.34 \mathrm{a}$ & $16.05 \mathrm{a}$ & $13.69 a b$ & $17.22 \mathrm{ab}$ & $36.91 \mathrm{a}$ & $263.67 b$ & $8656.7 \mathrm{c}$ \\
\hline V4 & $2.12 \mathrm{a}$ & $1.39 \mathrm{abc}$ & $1.09 \mathrm{cb}$ & $43.67 \mathrm{a}$ & $16.22 \mathrm{a}$ & $14.12 \mathrm{a}$ & $17.05 a b$ & $36.98 \mathrm{a}$ & $270.8 \mathrm{ab}$ & $9388.6 \mathrm{abc}$ \\
\hline V6 & $2.04 \mathrm{bc}$ & $1.35 \mathrm{~cd}$ & $1.03 \mathrm{cbd}$ & $43.4 \mathrm{a}$ & $16.03 \mathrm{a}$ & $13.33 b$ & $16.28 b$ & $37.08 \mathrm{a}$ & $270.65 a b$ & $8577.3 \mathrm{c}$ \\
\hline V8 & $2.02 \mathrm{~cd}$ & $1.31 \mathrm{~d}$ & $1.03 \mathrm{~cd}$ & $43.86 a$ & $15.97 \mathrm{a}$ & $13.97 \mathrm{a}$ & $16.72 a b$ & $36.49 \mathrm{a}$ & $276.88 a b$ & 8791.4 bc \\
\hline $\mathrm{V} 2+\mathrm{V} 4$ & $2.07 a b c$ & $1.41 a b$ & $1.01 \mathrm{~d}$ & $43.7 \mathrm{a}$ & $16.01 \mathrm{a}$ & $13.68 a b$ & $16.79 a b$ & $37.58 a$ & $270.14 a b$ & $8965.1 \mathrm{abc}$ \\
\hline $\mathrm{V} 2+\mathrm{V} 6$ & $2.05 \mathrm{bc}$ & $1.36 \mathrm{bcd}$ & $1.11 \mathrm{abc}$ & $43.52 \mathrm{a}$ & $16.03 \mathrm{a}$ & $13.8 \mathrm{a}$ & $16.92 a b$ & $36.51 \mathrm{a}$ & $274.35 a b$ & $9345.4 a b c$ \\
\hline $\mathrm{V} 2+\mathrm{V} 8$ & $2.07 \mathrm{abc}$ & $1.35 \mathrm{~cd}$ & $1.06 \mathrm{cbd}$ & $43.85 \mathrm{a}$ & $16.17 \mathrm{a}$ & $13.79 a$ & $17.41 \mathrm{ab}$ & $36.88 \mathrm{a}$ & $276.5 a b$ & $9283.9 a b c$ \\
\hline V4+V6 & $2.1 \mathrm{ab}$ & $1.42 \mathrm{a}$ & $1.81 \mathrm{a}$ & $43.79 \mathrm{a}$ & $16.23 \mathrm{a}$ & $13.84 \mathrm{a}$ & $17.19 a b$ & 37.09 a & $276.89 a b$ & $9780.6 \mathrm{a}$ \\
\hline$V 4+V 8$ & $2.07 \mathrm{abc}$ & $1.36 \mathrm{bcd}$ & $1.11 \mathrm{ab}$ & $44.01 \mathrm{a}$ & $16.04 \mathrm{a}$ & $14.06 \mathrm{a}$ & $17.61 \mathrm{a}$ & $37.06 \mathrm{a}$ & $277.37 \mathrm{ab}$ & $9678.5 a b$ \\
\hline$V 6+V 8$ & $1.96 \mathrm{~d}$ & $1.31 \mathrm{~d}$ & $1.09 \mathrm{cb}$ & $43.86 \mathrm{a}$ & $16.05 \mathrm{a}$ & $13.97 \mathrm{a}$ & $17.03 a b$ & $36.96 \mathrm{a}$ & $275.6 a b$ & $9116.7 a b c$ \\
\hline $\mathrm{V} 2+\mathrm{V} 4+\mathrm{V} 6+\mathrm{V} 8$ & $2.06 a b c$ & $1.36 \mathrm{bcd}$ & $1.10 \mathrm{abc}$ & $44.12 \mathrm{a}$ & $16.14 \mathrm{a}$ & $13.83 a$ & $17.11 \mathrm{ab}$ & $37.43 \mathrm{a}$ & $282.3 \mathrm{a}$ & $9678.2 a b$ \\
\hline CV\% & 6.1 & 8.1 & 13.2 & 3.4 & 5.2 & 6.1 & 12.8 & 7.5 & 9.9 & 18.3 \\
\hline
\end{tabular}

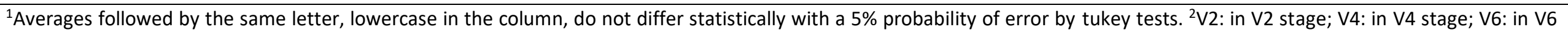

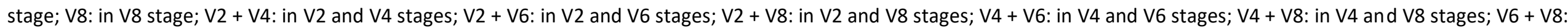
in V6 and V8 stages; V2 + V4 + V6 + V8: in V2, V4, V6 and V8 stages. 
Table 4: Averages for the characters cob diameter ( $C D, m m)$, grain mass per ear $(G M, g)$ and ear mass $(E M, g)$ for technology $x$ nitrogen management interaction.

\begin{tabular}{|c|c|c|c|c|c|c|c|c|}
\hline \multicolumn{3}{|c|}{$C D$} & \multicolumn{3}{|c|}{ GM } & \multicolumn{3}{|c|}{ EM } \\
\hline & & & \multicolumn{3}{|c|}{ Technology } & & \multirow[b]{2}{*}{ Conv } & \multirow[b]{2}{*}{ Trans } \\
\hline Management ${ }^{1}$ & Conv & Trans & Management & Conv & Trans & Management & & \\
\hline $\mathrm{V} 2^{2}$ & $22.63 \mathrm{abcA}$ & $22.06 \mathrm{bcA}$ & V2 & $160.62 \mathrm{abA}$ & 146.92 bB & V2 & $158.88 \mathrm{abA}$ & $137.08 \mathrm{~dB}$ \\
\hline V4 & $23.33 \mathrm{aA}$ & $22.3 \mathrm{bB}$ & V4 & $163.75 \mathrm{aA}$ & $150.81 \mathrm{aB}$ & V4 & 164.59 aA & 150.23 abcB \\
\hline V6 & $22.57 \mathrm{abcA}$ & $21.4 \mathrm{cB}$ & V6 & $162.54 \mathrm{abA}$ & 140.9 bB & V6 & $161.01 \mathrm{abA}$ & $140.94 \mathrm{cdB}$ \\
\hline V8 & 22.49 bcA & $22.76 \mathrm{abA}$ & V8 & $159.85 \mathrm{abA}$ & $151.71 \mathrm{aA}$ & V8 & $160.16 \mathrm{abA}$ & 148.76 abcdA \\
\hline $\mathrm{V} 2+\mathrm{V} 4$ & $22.98 \mathrm{abcA}$ & $23.4 \mathrm{aA}$ & $\mathrm{V} 2+\mathrm{V} 4$ & 150.96 bA & $156.9 \mathrm{aA}$ & $\mathrm{V} 2+\mathrm{V} 4$ & $149.29 \mathrm{bA}$ & $155.68 \mathrm{abA}$ \\
\hline $\mathrm{V} 2+\mathrm{V} 6$ & $22.89 \mathrm{abcA}$ & $22.39 \mathrm{bA}$ & $\mathrm{V} 2+\mathrm{V} 6$ & $163.22 \mathrm{abA}$ & 146.52 bB & $\mathrm{V} 2+\mathrm{V} 6$ & $163.48 \mathrm{aA}$ & 147.65 bcB \\
\hline $\mathrm{V} 2+\mathrm{V} 8$ & $22.31 \mathrm{cA}$ & 22.77 abA & $\mathrm{V} 2+\mathrm{V} 8$ & $158.85 \mathrm{abA}$ & $156.82 \mathrm{aA}$ & $\mathrm{V} 2+\mathrm{V} 8$ & $159.02 \mathrm{abA}$ & $154.35 \mathrm{abA}$ \\
\hline V4+V6 & 22.47 bcA & $22.72 \mathrm{abA}$ & V4+V6 & $160.62 \mathrm{abA}$ & $158.43 \mathrm{aA}$ & V4+V6 & $162.61 \mathrm{aA}$ & 156.86 abA \\
\hline V4+V8 & 23.12 abA & $22.08 \mathrm{bcB}$ & $\mathrm{V} 4+\mathrm{V} 8$ & $163.68 \mathrm{abA}$ & $145.41 \mathrm{bB}$ & $\mathrm{V} 4+\mathrm{V} 8$ & $164.46 \mathrm{aA}$ & $155.18 \mathrm{abA}$ \\
\hline V6+V8 & 22.52 bcA & $22.05 \mathrm{bcA}$ & $\mathrm{V} 6+\mathrm{V} 8$ & $157.77 \mathrm{abA}$ & $158.91 \mathrm{aA}$ & $\mathrm{V} 6+\mathrm{V} 8$ & $154.89 \mathrm{abA}$ & 156.57 abA \\
\hline $\mathrm{V} 2+\mathrm{V} 4+\mathrm{V} 6+\mathrm{V} 8$ & $23.13 \mathrm{abA}$ & $22.83 \mathrm{abA}$ & $\mathrm{V} 2+\mathrm{V} 4+\mathrm{V} 6+\mathrm{V} 8$ & $156.85 \mathrm{abA}$ & $162.43 \mathrm{aA}$ & $\mathrm{V} 2+\mathrm{V} 4+\mathrm{V} 6+\mathrm{V} 8$ & $158.73 \mathrm{abA}$ & $161.15 \mathrm{aA}$ \\
\hline $\mathrm{CV}(\%)$ & \multicolumn{2}{|c|}{5.07} & \multicolumn{3}{|c|}{12.3} & \multicolumn{3}{|c|}{12.2} \\
\hline
\end{tabular}

${ }^{1}$ Averages followed by the same letter, upper case in the line and lower case in column, do not differ at the 5\% probability level. ${ }^{2} \mathrm{~V} 2$ : in V2 stage; V4: in V4 stage; V6: in V6 stage; V8: in V8 stage; V2 + V4: in V2 and V4 stages; V2 + V6: in V2 and V6 stages; V2 + V8: in V2 and V8 stages; V4 + V6: in V4 and V6 stages; V4 + V8: in V4 and V8 stages; V6 + V8: in V6 and $\mathrm{V} 8$ stages; $\mathrm{V} 2+\mathrm{V} 4+\mathrm{V} 6+\mathrm{V} 8$ : in $\mathrm{V} 2, \mathrm{~V} 4, \mathrm{~V} 6$ and $\mathrm{V} 8$ stages. 
Table 5: Estimated parameters of the predictor model for grain yield of maize related to characters plant height (PH), ear height (EH), prolificity (PR), ear diameter $(E D)$, ear length (EL), number of grains per row (NG), number of rows per ear (NR), grain mass per ear (GM), cob diameter (CD), cob mass (CM), ear mass (EM) and thousand grains mass (TM).

\begin{tabular}{|c|c|c|c|c|c|c|c|c|c|c|c|c|c|c|}
\hline \multirow{2}{*}{ Character } & \multirow{2}{*}{ Treatment } & \multirow{2}{*}{ Intercept } & \multicolumn{12}{|c|}{ Explanatory characters of the predictor model } \\
\hline & & & $\mathrm{PH}$ & $\mathrm{EH}$ & PR & ED & EL & NG & NR & GM & $C D$ & $\mathrm{CM}$ & EM & TM \\
\hline \multirow{11}{*}{ GY } & $\mathrm{V}^{1}$ & 29873.00 & -4869.43 &.$^{*}$ & 6045.30 & . & -2246.07 & . & . & . & . & . & 45.30 & 45.89 \\
\hline & V4 & 13127.00 & . & . & . & . & -1703.03 & . & 1130.87 & -167.85 & . & . & 218.47 & . \\
\hline & V6 & -5026.49 & -1733.33 & . & . & . & 851.95 & . & . & -78.22 & . & . & 102.55 & . \\
\hline & V8 & 8689.80 & -6598.89 & . & . & 312.49 & . & . & . & . & . & . & . & . \\
\hline & $\mathrm{V} 2+\mathrm{V} 4$ & 27240.00 & -8322.48 & 6761.67 & . & . & . & . & -741.08 & . & . & . & . & . \\
\hline & $\mathrm{V} 2+\mathrm{V} 6$ & 11637.00 & -8472.06 & 5963.54 & 6120.18 & . & . & . & . & . & . & . & . & . \\
\hline & $\mathrm{V} 2+\mathrm{V} 8$ & 33192.00 & -11622.00 & 6847.32 & . & . & . & -153.22 & . & 58.57 & -536.78 & . & . & . \\
\hline & V4+V6 & 17874.00 & -8168.66 & 4632.28 & -1954.75 & . & . & . & . & . & . & . & . & 17.28 \\
\hline & $V 4+V 8$ & 5489.79 & -7865.75 & 7431.61 & 6941.47 & . & . & . & . & . & . & -350.24 & 54.32 & . \\
\hline & $\mathrm{V} 6+\mathrm{V} 8$ & 755.33 & -4759.54 & 7018.86 & . & . & -1885.86 & 536.95 & 956.38 & 51.23 & . & -586.90 & . & 27.80 \\
\hline & $\mathrm{V} 2+\mathrm{V} 4+\mathrm{V} 6+\mathrm{V} 8$ & 15017.00 & -7611.68 & 5356.20 & -2752.76 & . & . & . & . & . & . & . & 38.21 & \\
\hline
\end{tabular}

${ }^{*}$ coefficient not significant at $5 \%$ probability by the Tukey test. ${ }^{1} \mathrm{~V} 2$ : in V2 stage; V4: in V4 stage; V6: in V6 stage; V8: in V8 stage; V2 + V4: in V2 and V4 stages; V2 + V6: in V2 and V6 stages; V2 + V8: in V2 and V8 stages; V4 + V6: in V4 and V6 stages; V4 + V8: in V4 and V8 stages; V6 + V8: in V6 and V8 stages; V2 + V4 + V6 + V8: in $\mathrm{V} 2, \mathrm{~V} 4, \mathrm{~V} 6$ and $\mathrm{V} 8$ stages. 
In the treatment V2 nitrogen fertilization favored higher yield due to higher prolificacy, grain mass per ear and thousand grain mass, but it was not favored by plant height and ear length (table 5). Nitrogen fertilization at this stage provided a grain yield $6 \%$ lower than the average of treatments (figure 1 ).

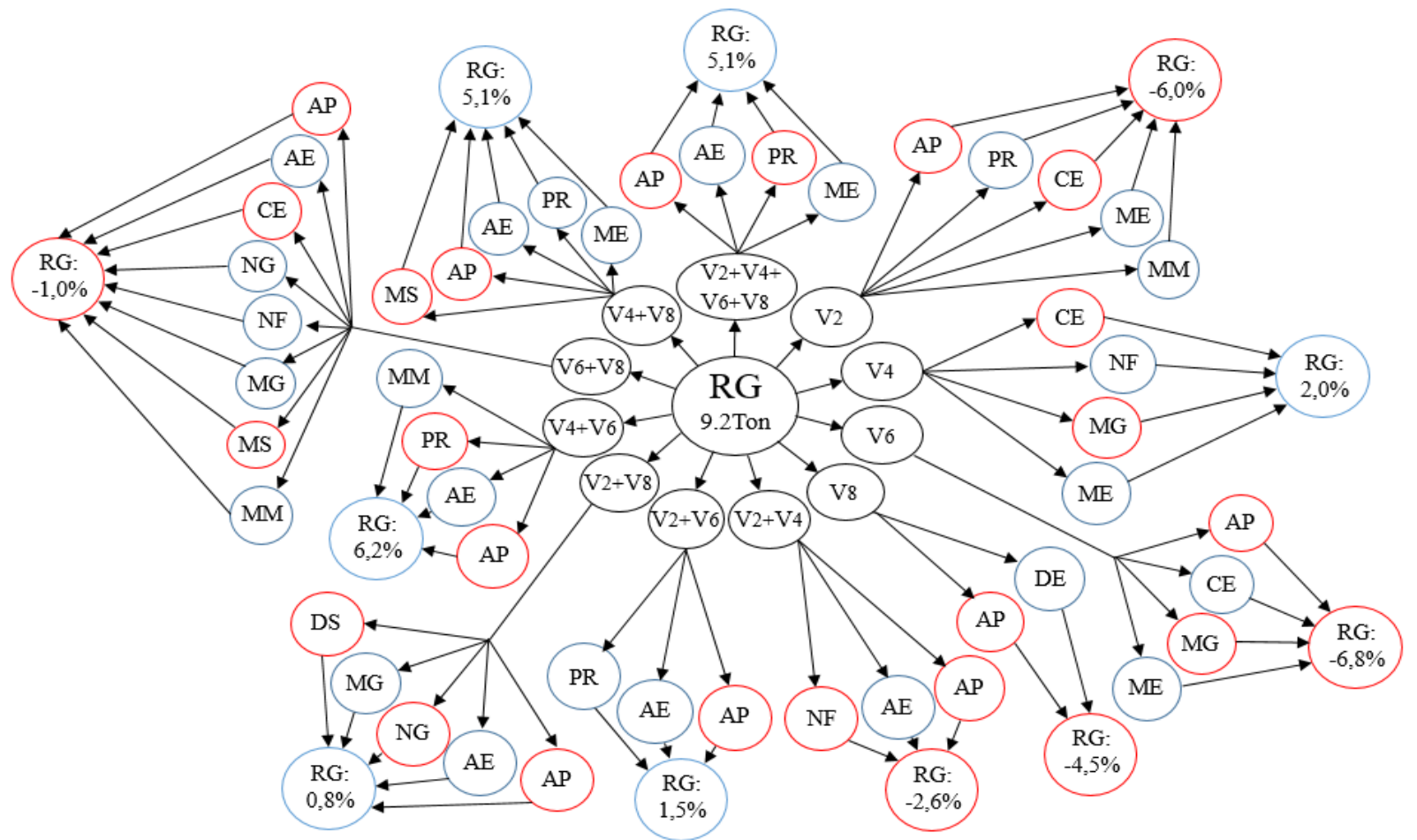

Figure 1: Causal diagram of grain yield of maize referring to the efficient management of nitrogen for different phenological stages. Plant height $(\mathrm{PH})$, ear height $(\mathrm{EH})$, prolificity $(\mathrm{PR})$, ear diameter (ED), ear length (EL), number of grains per row (NG), number of rows per ear (NR), grain mass per ear (GM), cob diameter (CD), cob mass (CM), ear mass (EM), thousand grains mass (TM), yield (YI). V2 stage (V2), V4 stage (V4), V6 stage (V6), V8 stage (V8), V2 and V4 stages (V2+V4), V2 and V6 stages (V2+V6), V2 and V8 stages $(\mathrm{V} 2+\mathrm{V} 8), \mathrm{V} 4$ and $\mathrm{V} 6$ stages (V4+V6), $\mathrm{V} 4$ and $\mathrm{V} 8$ stages (V4+V8), $\mathrm{V} 6$ and $\mathrm{V} 8$ stages (V6+V8); $\mathrm{V} 2, \mathrm{~V} 4, \mathrm{~V} 6$ and $\mathrm{V} 8$ stages $(\mathrm{V} 2+\mathrm{V} 4+\mathrm{V} 6+\mathrm{V} 8)$.

In nitrogen fertilization in V4, grain yield is favored by higher number of rows per ear and ear mass, not being favored by ear length and grain mass (Table 5 ). Grain yield with nitrogen fertilization at this stage was higher than the average by $2 \%$.

In the treatment with nitrogenous fertilization in V6, the highest grain yield was influenced by a higher ear length and ear mass, but plant height and did not favor higher yields. The grain yield of plants with nitrogen fertilization in $V 6$ was $6.8 \%$ lower than the average of the treatments.

The yield with V8 treatment was favored by better characteristics of ear diameter in contrast to plant height. The grain yield was $4.5 \%$ lower when nitrogen was applied in V8 stage in relation to the average of the treatments.

The grain yield for the treatment with splitted nitrogen fertilization in the V2 + V4 stages is favored by plants with higher ear insertion height and disadvantaged by ear with smaller number of rows and plants with smaller height. The application of nitrogen in V2 + V4 reflected in $2.6 \%$ lower grain yield.

Nitrogen fertilization in V2 + V6 favored the grain yield as it allowed the development of plants with higher prolificacy and higher ear insertion height, but the very high plant height contributed negatively to the yield. Nitrogen applications in this treatment favored a productivity 1,5\% higher than the average of the treatments.

Splitted nitrogen management in V2 + V8 favored a grain yield higher than the average of other treatments in $0.8 \%$. This result was favored by plants with higher grain mass and ear height, but the high cob diameter, low number of grains per row and very high plant height contributed negatively to grain yield.

Nitrogen management in the V4 + V6 stages reflected a grain yield of $6.2 \%$ higher than the average of the treatments, favoring the development of maize plants with greater thousand grain mass and higher ear insertion height, but plants with lower prolificacy and very high plant height were unfavorable to grain yield 
For the treatment with nitrogen management in the $V 6+V 8$ stages grain yield is favored by plants with higher ear insertion height, higher number of grains per row, larger number of rows, greater grain mass per ear and larger thousand grain mass, but characteristics such as very high plant height, very short ear length, and very high cob mass negatively influence the yield.

The treatment with nitrogen management in the $\mathrm{V} 4+\mathrm{V} 8$ stages favored grain yield by producing plants with higher ear mass, greater prolificacy and higher ear insertion height, but negatively influenced by characteristics of excessive plant height and very high cob mass. The grain yield with nitrogen splitting in V4 $+\mathrm{V} 8$ was $5.1 \%$ higher than the average of the other treatments.

For the management of nitrogen fertilization in the $\mathrm{V} 2+\mathrm{V} 4+\mathrm{V} 6+\mathrm{V} 8$ stages, grain yield is favored by plants with higher ear insertion height and greater ear mass, but excessive plant height and low prolificacy negatively influence yield. This treatment allowed a higher grain yield in $5.1 \%$.

The effect of nitrogen management was positive in $\mathrm{V} 4$ stage and in nitrogen splitting doses in $\mathrm{V} 4+\mathrm{V} 6, \mathrm{~V} 4$ + V8 and V2 + V4 + V6 + V8, according to Magalhães et al. (2002), who verified that in maize plants, in the V3 stage the number of leaves and ears per plant is defined, and until V8 the number of grains and rows per ear are defined. In the phenological stage of $\mathrm{V} 4$ occurs the definition of the maximum productive potential defined by virtue of the differentiation of the apical meristem in maize plants and definition of the number of ovules for the formation of the ear. In V8 occurs the beginning of the increase of the growth rate of ears (Fancelli \& Dourado-Neto, 2004; Fornasieri-Filho, 2007).

\section{CONCLUSIONS}

There was interaction between genetic technologies and levels of nitrogen fertilization in the maize crop.

The highest grain yield was obtained with conventional technology because it presented plants with greater prolificacy, ear diameter and number of grains per row.

Grain yield was superior with nitrogen fertilization in V4 and in nitrogen splitting in the V4 + V6, V4 + V8 and $\mathrm{V} 2+\mathrm{V} 4+\mathrm{V} 6+\mathrm{V} 8$ stages.

\section{REFERENCES}

Andrade, F. R., Petter, F. A., Nóbrega, J. C. A., Pacheco, L. P., \& Zuffo, A. M. (2014). Desempenho agronômico do milho a doses e épocas de aplicação de nitrogênio no Cerrado piauiense. Revista de Ciências Agrarias - Amazonian Journal of Agricultural and Environmental Sciences, 57(4), 358-366. https://doi.org/10.4322/rca.1295

Arf, O., Rodrigues, R. A. F., Nascente, A. S., \& Lacerda, M. C. (2015). Adubação antecipada de nitrogênio na cultura do arroz de terras altas sob plantio direto. Revista de Ciências Agrarias - Amazon Journal of Agricultural and Environmental Sciences, 58(1), 6-13. https://doi.org/10.4322/rca.1625

Beatty, P. H., Anbessa, Y., Juskiw, P., Carroll, R. T., Wang, J., \& Good, A. G. (2010). Nitrogen use efficiencies of spring barley grown under varying nitrogen conditions in the field and growth chamber. Annals of Botany, 105(7), 1171-1182. https://doi.org/10.1093/aob/mcq025

Büll, L. T. (1993). Cultura do milho: fatores que afetam a produtividade. In H. Bull, L.T., \& Cantarella (Ed.), Nutrição mineral do milho. (pp. 63-145). Piracicaba, SP: Potafos.

CONAB - Companhia Nacional de Abastecimento. (2018). Acompanhamento da Safra Brasileira de Grãos. V. 5 - SAFRA 2017/18- N. 12 - Décimo segundo levantamento, 2018. Retrieved from https://www.conab.gov.br/info-agro/safras/graos/boletim-da-safra-de-graos

CQFS-RS/SC - Comissão de Química e Fertilidade do Solo - RS/SC. (2004). Manual de calagem e adubação para os Estados do Rio Grande do Sul e de Santa Catarina. Porto Alegre, RS: Sociedade Brasileira de Ciência do Solo. Retrieved from http://www.sbcs-nrs.org.br/?secao=publicacoes

Crawford, T. W., Rendig, V. V., \& Broadbent, F. E. (1982). Sources, Fluxes, and Sinks of Nitrogen during Early Reproductive Growth of Maize ( Zea mays L.) . Plant Physiology, 70(6), 1654-1660. https://doi.org/10.1104/pp.70.6.1654 
Deng, F., Wang, L., Mei, X. F., Li, S. X., Pu, S. L., Li, Q. P., \& Ren, W. J. (2019). Polyaspartic acid (PASP)-urea and optimised nitrogen management increase the grain nitrogen concentration of rice. Scientific Reports, 9(1), 1-9. https://doi.org/10.1038/s41598-018-36371-7

Escanferla, M., Wysmierski, P., Meirelles, W. F., \& Paccola-Meirelles, L. D. (2018). Viability and dissemination of Pantoea ananatis, etiological agent of Maize White Spot disease. Agronomy Science and Biotechnology, 4(2), 52. https://doi.org/10.33158/asb.2018v4i2p52

Fancelli, A. L., \& Dourado-Neto, D. (1997). Fenologia do milho. In D. Fancelli, A. L., \& Dourado-Neto (Ed.), Tecnologia da produção de milho (pp. 131-140). Piracicaba, SP: Publique.

Fancelli, A. L.; \& Dourado-Neto, D. (2004). Produção de milho (2nd ed.). Guaíba: Agropecuária.

Fornasieri-Filho, D. (2007). Manual da cultura do milho. Jaboticabal, SP: Funep.

Kappes, C., Carvalho, M. A. C., Yamashita, O. M., \& Silva, J. A. M. (2009). Influência Do Nitrogênio No Desempenho Produtivo. Pesquisa Agropec. Trop., 39(3), 251-259.

Magalhães, P. P., Durães, F. O. M., Carneiro, N. P., \& Paiva, E. (2002). Fisiologia do Milho (Circular T). Sete Lagoas, MG: EMBRAPA-CNPMS.

Mar, G. D., Marchetti, M. E., Souza, L. C. F., Gonçalves, M. C., \& Novelino, J. O. (2003). Produção do milho safrinha em função de doses e épocas de aplicação de nitrogênio. Bragantia, 62(2), $267-274$. https://doi.org/10.1590/s0006-87052003000200012

Mir, M. R., Mobin, M., Khan, N. A., Bhat, M. A., Lone, N. A., Bhat, K. A., ... Payne, W. A. (2010). Crop Responses to Interaction between Plant Growth Regulators and Nutrients. Journal of Phytology, 2010(10), 9-19. Retrieved from www.journal-phytology.com

Moda, L. R., Santos, C. L. R., Flores, R. A., Borges, B. M. M. N., Andrioli, I., \& Prado, R. D. M. (2014). Resposta do milho cultivado em sistema de plantio direto à aplicação de doses de nitrogênio e cultivo de plantas de cobertura em pré-safra. Bioscience Journal, 30(3 SUPPL. 1), 178-187.

Okumura, R. S., Mariano, D. D. C., Vicente, P., \& Zaccheo, C. (2011). Uso de fertilizante nitrogenado na cultura do milho : uma revisão. Revista Brasileira de Tecnologia Aplicada nas Ciências Agrárias, 6325, $226-235$.

Queiroz, A. M., Souza, C. H. E., Machado, V. J., Lana, R. M. Q., Korndorfer, G. H., \& Silva, A. D. A. (2011). Revista Brasileira de milho e sorgo. Revista Brasileira de Milho e Sorgo, 10(3), 257-266. Retrieved from http://rbms.cnpms.embrapa.br/index.php/ojs/article/view/355/pdf_15

Rosa, T. C. da, Carvalho, I. R., Hutra, D. J., Bradebon, L. C., Sarturi, M. V. da R., Rosa, J. A. G. da, \& Szareski, V. J. (2021). Maize breeding for abiotic stress tolerance: An alternative to face climate changes. Agronomy Science and Biotechnology, 6, 1-13. https://doi.org/10.33158/asb.r119.v6.2020

Sangoi, L., Vargas, V. P., Schimitt, A., Pletsch, A. J., Vieira, J., Saldanha, A., ... Picoli Junior, G. J. (2011). Disponibilidade de nitrogênio, sobrevivência e contribuição dos perfilhos ao rendimento de grãos do milho. Revista Brasileira de Ciencia Do Solo, 35(1), 183-191. https://doi.org/10.1590/S010006832011000100017

Santos, R. J. dos, Bizzarri, J. H., Barbosa, A. P., \& Zucareli, C. (2017). Molybdenum application forms associated to topdressing nitrogen fertilization in the production of maize crops. Agronomy Science and Biotechnology, 3(2), 105. https://doi.org/10.33158/asb.2017v3i2p105

Sauer, A. V., Rocha, K. R., Gonçalves, R. M., Meirelles, W. F., Figueiredo, J. E. F., Marriel, I. E., \& PaccolaMeirelles, L. D. (2015). Survival of pantoea ananatis, causal agent of maize white spot disease in crop debris. Agronomy Science and Biotechnology, 1(1), 21. https://doi.org/10.33158/asb.2015v1i1p21 
Sims, A. L., Schepers, J. S., Olson, R. A., \& Power, J. F. (1998). Irrigated corn yield and nitrogen accumulation response in a comparison of no-till and conventional till: Tillage and surface-residue variables. Agronomy Journal, 90(5), 630-637. https://doi.org/10.2134/agronj1998.00021962009000050011x

Souza, J. A., Buzetti, S., Teixeira-Filho, M. C. M., Andreotti, M., Sá, M. E., \& Arf, O. (2011). Adubação nitrogenada na cultura do milho safrinha irrigado em plantio direto. Bragantia, 70(2), 447-454. https://doi.org/10.1590/S0006-87052011000200028

Zucareli, C., Alves, G. B., Oliveira, M. A., \& Machado, M. H. (2014). Desempenho agronômico do milho safrinha em resposta às épocas de aplicações e fontes de nitrogênio. Científica, 42(1), 60. https://doi.org/10.15361/1984-5529.2014v42n1p60-67

Received: January 21, 2021.

Accepted: March 9, 2021.

Published: April 27, 2021.

\section{English by: Francine Lautenchleger.}

